Proceedings of the 24th International Symposium "The Environment and the Industry" (E-SIMI 2021), 24 September 2021, online event

\title{
Exposure assessment using biomonitoring
}

\author{
ANDREEA COZEA $^{1 *}$, GHEORGHITA TANASE $^{1}$, MIHAELA NEAGU $^{2}$ \\ ${ }^{1}$ National Research and Development Institute for Industrial Ecology ECOIND, 57-73 Drumul Podu Dambovitei Street, \\ district 6, 060652, Bucharest, Romania \\ ${ }^{2}$ S.C. Hofigal S.A. No. 2 Street Intrarea Serelor, postal code 042124, District 4, Bucharest, Romania \\ *Corresponding author:andreea.cozea@yahoo.com
}

$\begin{array}{lll}\text { Received: } & \text { Accepted: } & \text { Published: } \\ \text { 07.09.2021 } & 16.12 .2021 & 17.12 .2021\end{array}$

\begin{abstract}
Complex studies were performed combining macroscopic and biochemical analyzes of selected biomonitors, exposed in exposure systems outdoor with mixtures of pollutants as well as controlled exposure with certain concentrations of pollutants in fumigation chambers. In this study, the following plant species were used as bioindicators: Nicotiana tabacum, Petunia hybrida, Ricinus comunis, Trifolium pretense. The exposure plant samples were compared with control samples of biomonitors maintained under standardized conditions in the climate chamber. Classical methods of biochemistry combined with those of exposure biomonitoring have led to the completion of knowledge about the ways of action of plants to pollution. The analysis of some of the antioxidant compounds that are representing a structural class of chemicals (enzymes) with a wide range of biological functions, with the role of free radical inhibition, was performed. Many of the constituent compounds in certain cell types, also called active compounds, in this case polyphenols are present in the body of some plant species. Polyphenols presence in organisms, that are not usually present or are in normal quantities, is caused by stress, (pollution being a stress factor). Large amounts of polyphenols in plants are also given by the presence of pollutants in the environment. Through these extensive combined studies, it has been demonstrated that pollution can be a degenerative factor at the biochemical and physiological level, at the plant tissue level, with irreversible effects.
\end{abstract}

Keywords: antioxidant capacity, bioindicator plants, industrial pollution, TPC, TFC

\section{INTRODUCTION}

Large-scale industrial development, already known, the practice of intensive agriculture, as well as the massive transfer of industrial and agricultural technologies, in socio-economic spaces insufficiently prepared for their assimilation, have highlighted, through the effects of pollution generated by industry and agriculture, the need to identify polluted areas and what will generate long-term actions and measures to maintain the natural balance [1].

The multitude of relationships between the elements of the ecosystem, as well as the high degree of interdisciplinary of research is closely related to the formulation of models for methods of measuring biotope parameters, monitoring the level of pollution, and monitoring the evolution of ecosystems [2].

Generally, air monitoring refers to the monitoring of air pollution sources, stipulating the values of the parameters of the most important pollutants compared to the limits imposed by law, but in our case is used biological monitoring that can provide an insight into the effects of pollution on organisms. From this point of view, living organisms, in our case some plant species, are very 
important to highlight the effects of pollution, because they have some additional advantages compared with classical air monitoring analyses [3].

Living organisms can continuously "record" the physical and chemical changes that have occurred in their living environment, by accumulating over time, information that is found in their various organs or tissues.

The aim of the biomonitoring studies was to identify bioindicators that provide information regarding the stability of ecosystems, the maintenance of biodiversity, and the sustainable management of ecosystems and recording the information on the response of ecosystems to global climate change.

A biomonitor called also bioindicator is a living organism or a group of organisms whose function, population or status may reveal environmental information [4].

The possibility of using such organisms as biological indicators in monitoring the quality of the environment and identifying changes, has proved extremely useful given that the functional relationships between pollutant factors and the type of response of species that could be very well studied and understood [5].

Bioindicators for pollution have the advantage over instrumental classical air monitoring that they can provide a response to the combined effect of certain pollutants, as opposite to instrumental measuring that identify the quantities of each pollutant separately) and can give indications, following tissue analysis, related to very low levels of environmental pollutants, as well as the evolution of the pollutants over time, on longer periods.

Bioindicators, in this case, are cultivated species, generally herbaceous plants and fast-growing, genetically uniform, generically called "sentinel species" (their use is subject to the active method of biomonitoring used in Standard SR EN 16789:2017) [6].

However, the fast reaction is characteristic only of the juvenile stages of plant growing and therefore the plants must be reintroduced periodically. They are previously grown in pollutant-free air and then introduced to the monitored areas and their reaction to the pollutants is observed along a time period. Early warning of specialists allows decision makers to take measures regarding the environment protection, to remedy the situation, before irreversible negative effects occur.

Currently, the largest ecosystem biomonitoring monitoring network is in Europe. Biomonitoring is preferable to instrumental monitoring, if sufficient financial resources are not available for the placement and maintenance of sophisticated equipment and it is very convenient for cases where large-scale monitoring of large areas, is performed for a long time. Biomonitoring is preferable to instrumental monitoring, if laboratory's not has sufficient financial resources to place and maintain sophisticated equipment [7,8].

In the next paragraphs are explained the importance of the antioxidant compounds and reviewed the plant physiology for understanding the way of acting plant antioxidants as own, ,therapeutic entities".

Phenols are antioxidant compounds and the excess of phenols are considered important biomarkers for the phytotoxic effects of heavy metals and other pollutants. Increasing the production of phenolic compounds is part of the plant's defence mechanism. Phenolic compounds are of particular interest because of their involvement in the stress response, such as intra and/or interspecific on air pollution. Polyphenols are produced in the cytoplasm and form droplets in vacuoles that will later evolve into a single vacuole. If the excess of polyphenols occurs, the cytoplasm degenerate, the organs disappear and, eventually, the release of the vacuoles content leads to the death of the mesophilic cells [9].

Flavonoids have been considered as a secondary system of ROS (reactive oxygen species) elimination in plants suffering from photosynthetic damage due to excess of excitation energy [10]. They also play a role in the elimination of $\mathrm{O}_{2}$ and alleviate the damage caused to the outer shell of the chloroplast membrane. Flavonoids as well as other phenolic compounds are commonly known as secondary metabolites of plants that have an aromatic ring that carries at least one hydroxyl group. In plants, secondary metabolites, especially phenolic compounds (e.g., phenols and flavonoids) are of great importance in plant-environment relationships. These compounds are of 
particular interest due to their involvement in the plant's response to environmental stress, such as nutrient deficiency, the impact of ultraviolet (UV) rays, or air pollution.

In response to increased oxidative stress, plants grows the production and accumulation of several low molecular weight antioxidants (e.g., vitamin $\mathrm{C}$, vitamin $\mathrm{E}$, phenolic acids, etc.) and high molecular antioxidant secondary metabolites such as tannins, which confer antioxidants to most plants under studies by functioning as free radical scavengers.

The role of antioxidants is to destroy the free radicals of the cell that have a negative effect on living organisms. A special role in neutralizing the effects of oxidative stress belongs to the enzyme superoxidysmutase (SOD). SOD is a metalloenzyme with a structural subunit organization and represent the main regulator of oxidation processes in the cell, which catalyses the recombination reaction of $\mathrm{O}_{2}$ radicals.

The natural supplementation of antioxidants or boosting endogenous antioxidant defences of the tissues are a promising way of combating the undesirable effects of reactive oxygen species (ROS) induced oxidative damage. Plants have an innate ability to biosynthesize a wide range of nonenzymatic and enzymatic antioxidants capable of attenuating ROS- induced oxidative damage.

Different plant species vary considerably in terms of their sensitivity to air pollutants. The identification and classification of plants into sensitive and tolerant categories is important, as the former can serve as indicators, and can be means of reducing air pollution in urban and industrial habitats.

To indicate the sensitivity level of a plant, pollution-induced changes in individual parameters are usually quantified and correlated with the plant's response level. The Air Pollution Tolerance Index (APTI) is an inherent quality of plants that face the stress of air pollution, which is currently used, especially in industrial and non-industrial areas [11]. In addition, the APTI index shows the level of plant sensitivity for pollution-induced changes in the environment.

The aim of the present study was to demonstrate that pollution has significant effects on total phenolic, flavonoid and superoxide dismutase levels in plants, not only demonstrating the effects of pollution on ecosystem health. The study used the biomonitoring assessment, as a way of developing research skills regarding the use of plants as biological tools in air monitoring, an innovative approach for Romania. In the present study, the APTI index was evaluated in industrial and non-industrial sites. Consequently, the findings of research besides the complexity, it is important to highlight the effects of pollution, which also contribute to modifying biochemical composition and plant aspect.

\section{MATERIALS AND METHODS}

\section{Plant samples}

In this study, the following plant species were used as bioindicators: Nicotiana tabacum, Petunia hybrida, Ricinus comunis, Trifolium pretense. These plants were grown and maintained under standardized conditions in the climate chamber and subsequently exposed in three industrially polluted areas, as well as experimental laboratory tests by exposure to fumigation chambers. After two weeks exposure, leaves were detached and analysed.

\section{Stages of plant development}

For the development of biomonitoring tests, it was necessary to prepare the plant material for exposure respecting the following steps: i) selection of seeds for study; ii) seed treatment; iii) seed germination; iv) preparation of biomonitor plants for exposure as shown in figure 1 . 


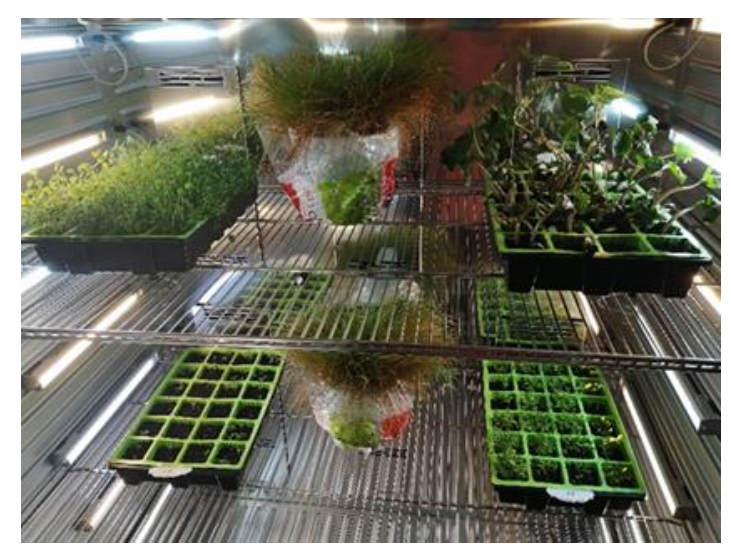

Fig. 1. Seedlings developed in the climatic chamber

The development parameters of the plants were: temperature at $18-20^{\circ} \mathrm{C}$, with a relative humidity of $60-75 \%$, photosynthetic active radiation (PAR) of $130-150 \mu \mathrm{mol} \mathrm{m} / \mathrm{s}$ made by Whitelux Plus metal halide lamps and a 16/8 hours day/night regime in a growth chamber type HPP Climatic Chambers Peltier technology Manufacturer: MEMMERT, Germany.

Prior to exposure, seedlings were transferred to pots with a standardized soil mixture, adjusting the soil $\mathrm{pH}$ to 6.5-7 and the soil moisture being adjusted to $70 \%$ (figure 2).

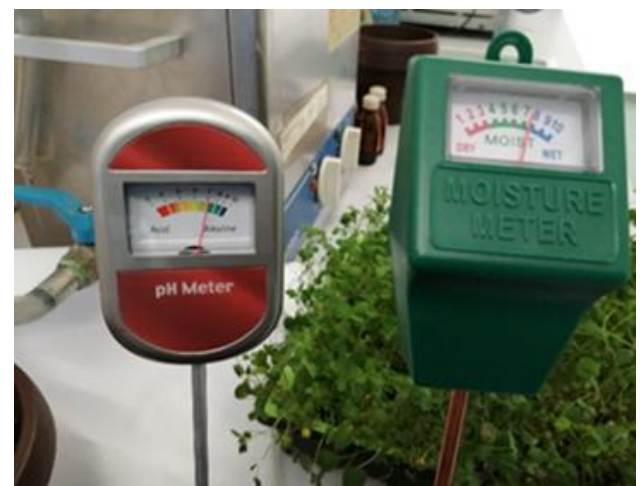

Fig. 2. Preparing plants for exposure and checking soil quality

\section{Monitoring exposure sites}

There were three environmental sites around Bucharest:

1. Incinerator site - site 1 of exposure

2. Chicken farm site - site 2 of exposure

3. Site with slaughterhouse - site 3 of exposure

Taking into account the geographical position, the temperate-continental character of the climate in the exposure areas is easily noticed: the maximum temperature reached values of $34^{\circ} \mathrm{C}$ (July), the minimum temperature was $16^{\circ} \mathrm{C}$, and the average during the exposure $26^{\circ} \mathrm{C}$.

Figure 3 indicates the exposure sites of the bioindicator plants.

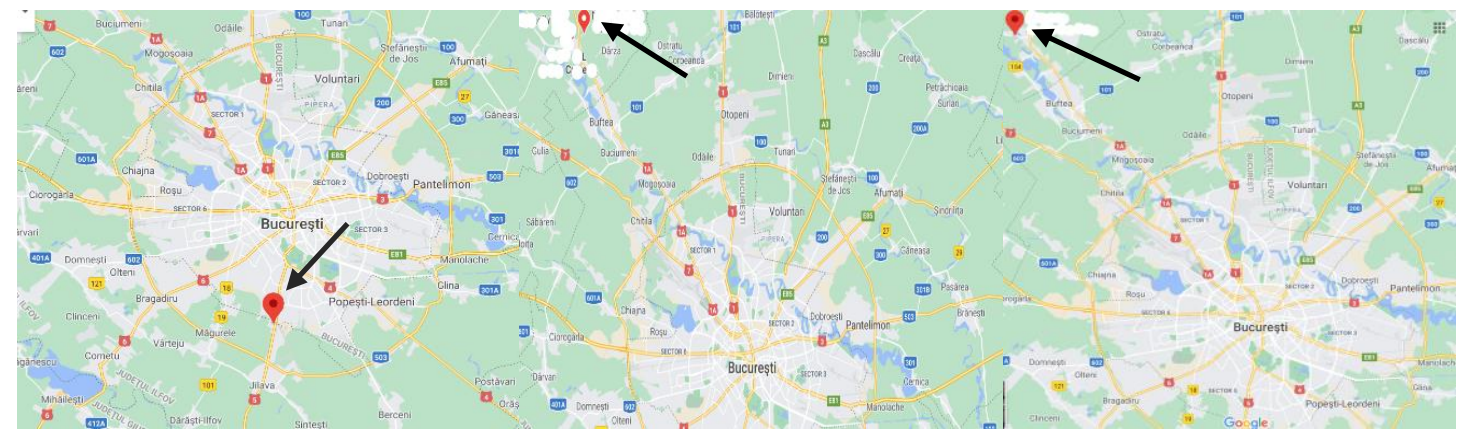

Exposure site 1
Exposure site 2

Exposure site 3

Fig. 3 Bio indicator exposure sites 
The duration of the procedures for air pollution exposure was 14 days for each monitoring set, the period in which the changes that occurred during this period were followed [8]. The exposure was carried out in the three environmental sites but also in a specially designed fumigation enclosure, in the laboratory (figure 4) where a mixture of pollutants was introduced, as seen in.

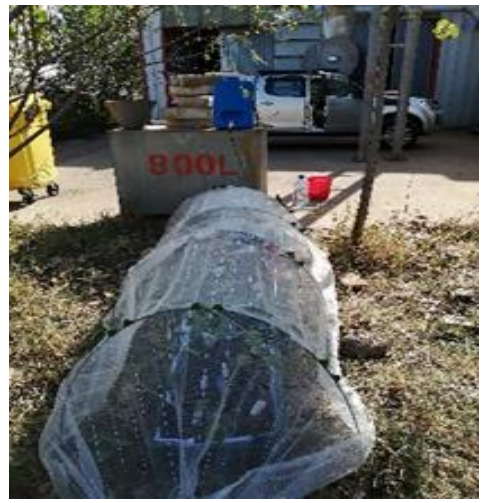

a)

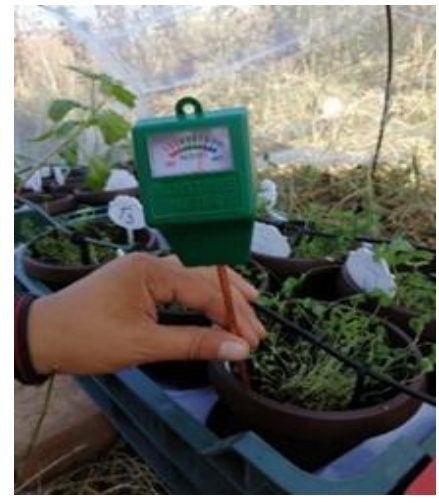

b)

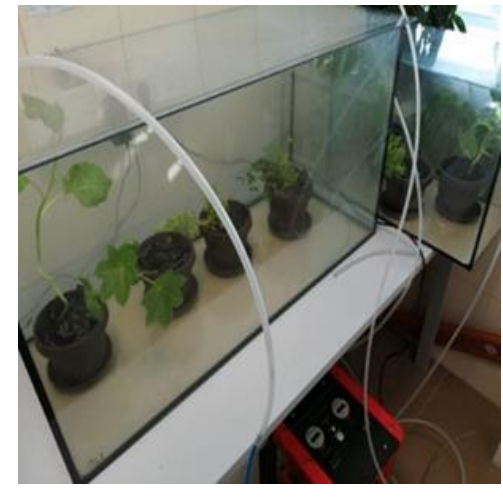

c)

Fig. 4. Exposure of monitoring assemblies: a), b) in sites and c) in fumigation chamber

\section{Sample processing}

A quantity of $0.5-5 \mathrm{~g}$ of fresh or dry sample (plant material) is extracted with $50 \% \mathrm{EtOH}$ solvent in a reflux flask for 30 minutes. The sample is cooled and filtered on Whatman quality filter paper with size $\varnothing=150 \mathrm{~mm}$ and then brought to the mark on a flask rated with the same solvent.

\section{Biochemical analyses performed}

A strong point of the biomonitoring study was the extensive evaluation of all procedural stages from plant cultivation, exposure in monitoring sites, measurements, to data processing. Through this strict harmonization, the aim was to eliminate, as far as possible, any risks of methodological error considered to be particularly high.

For the biomonitoring studies, the following methods were applied, to some samples and controls from the bioindicators selected for the study, and from the obtained results it was possible to draw conclusions:

\section{The total polyphenol content (TPC)}

The total polyphenol content (TPC) (expressed in Gallic acid equivalent) was performed by the Folin-Ciocalteu method, using as standard the Gallic acid $(\mu \mathrm{g} / \mathrm{mL})(\lambda=765 \mathrm{~nm})(\mathrm{mg} / \mathrm{g})$ sample. Principle of the method: in the basic medium and in the presence of phenols in the mixture of phosphotungistic and phosphomolybdenic acids from the Folin-Ciocalteu reagent are reduced to blue oxides of fungist and molybdenum [13]. This blue coloration has a maximum of absorption at the wavelength of $765 \mathrm{~nm}$ and the coloration and is proportional to the content of polyphenolic compounds. Using the Folin-Ciocalteu method, the $\mathrm{OH}$ groups in the study sample can be measured under alkaline conditions (adjusted with sodium carbonate). The increase in absorbance at a wavelength of $765 \mathrm{~nm}$ increases in proportion to the number of $\mathrm{OH}$ groups. The total polyphenol content was expressed in Gallic acid equivalent $(\mathrm{mg} / \mathrm{g})$ of the sample.

\section{Total flavone content (TFC)}

Determination of total flavone content (TFC) was performed by the method described by Marinova [12] spectrophotometric in the presence of aluminium chloride, using as analytical standard in quercetin $(\mu \mathrm{g} / \mathrm{mL})(\lambda=510 \mathrm{~nm})$.

The principle of the method is based on the formation of a light reddish brown coloured complex based on the reaction between flavonoids and aluminium chloride in a weakly acidic medium. The total flavonoid content was expressed in equivalent in quercetin $(\mathrm{mg} / \mathrm{g})$ sample. 


\section{Antioxidant activity}

Antioxidant capacity (expressed in Trolox) by the CUPRAC method. The antioxidant activity was determined using a Jasco spectrophotometer, based on a calibration curve using as standard Trolox (antioxidant substance), $(\lambda=450 \mathrm{~nm})$ of known concentrations [14, 15]. This determination is important for evaluating the relationship between diet and oxidative stress [16].

The principle of the method is based on changes in the specific absorbance of the copperneocuproin complex when reduced by an antioxidant. The total reduction content of cupric ion was expressed in the Trolox equivalent ( $\mathrm{mg} / \mathrm{g}$ ) sample. In other words, the reducing potential [17] of the sample to be analysed causes the $\mathrm{Cu}_{2}{ }^{+}$ion to be reduced to $\mathrm{Cu}{ }^{+}$, according to the figure 5 below:

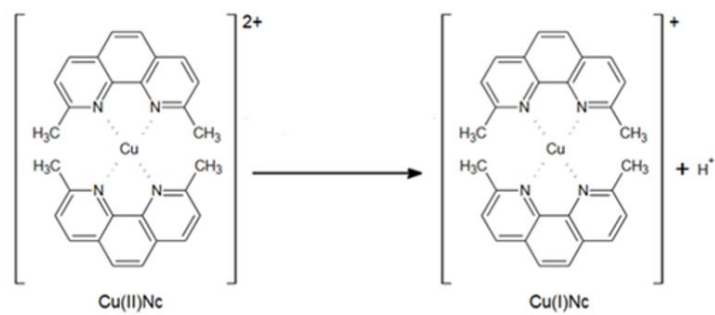

Fig. 5. Reduction of the copper-neocuproin complex [17]

Antioxidants are compounds that have the ability to delay or to inhibit the oxidation processes of various types of reactive species, thus being involved in the body's defence mechanisms against free radicals $[18,19]$.

\section{Air Pollution Tolerance Index (APTI)}

To assess the level of sensitivity of plants to air pollutants, four parameters were determined and calculated, namely: ascorbic acid, chlorophyll, relative water content and $\mathrm{pH}$ of the plant extract, in a formulation indicating the tolerance index to air pollution (APTI). After a careful analysis of the contribution of each parameter (ascorbic acid, chlorophyll, relative water content and $\mathrm{pH}$ extracted from the leaves), these parameters were evaluated together in a calculation formula to obtain an empirical value indicating the index of tolerance to air pollution $[19,20]$.

$$
A P T I=\frac{A(T+P)+R}{10}
$$

where:

A = Ascorbic acid

$\mathrm{T}=$ Total chlorophyll

$\mathrm{P}=\mathrm{pH}$ of the leaf extract

$\mathrm{R}=$ Relative water content

\section{RESULTS AND DISCUSSION}

At the end of the two-week exposure period, the extent of the lesions caused on the reference leaves was recorded and the exposed plants were evaluated.

The antioxidant capacity of the extracts obtained from the plants exposed to pollutants samples were compared to the control ones, in order to highlight the degree of inhibition of free radicals decreases in the exposed plants compared to the control ones.

Plant Leaves 1-4 served as reference leaves for damage assessment and for sampling analysis. Such values were taken into account at the end of the two-week period of the plants exposed in 3 environmental sites: Incinerator site $-(\mathrm{P} 1)$, chicken farm site $-(\mathrm{P} 2)$, site with slaughterhouse (P3), as well as in the fumigation chambers - (P4) and climatic chamber with Control plants (P5). The results obtained for all the plant species Nicotiana tabacum, Petunia hibrida, Ricinus comunis, Trifolium pratense in terms of Total flavone content (TFC) (expressed in quercetin), mg/g; Total polyphenol content (TPC) (expressed as Gallic acid), mg/g; Antioxidant capacity (AO) "CUPRAC method" (expressed in Trolox), mg/g, are presented in tables 1 to 4. 
Table 1. The concentrations of total flavones, total polyphenols and antioxidant activity for $N$. tabacum from exposure sites

\begin{tabular}{c|ccc}
\hline Samples & TFC quercetin, $\mathrm{mg} / \mathrm{g}$ & TPC Gallic acid, $\mathrm{mg} / \mathrm{g}$ & AO Trolox, $\mathrm{mg} / \mathrm{g}$ \\
\hline P1 & 13.60 & 5.90 & 13,76 \\
P2 & detection below & 0.35 & 0.71 \\
P3 & 11.20 & 1.20 & 9.76 \\
P4 & 10.60 & 3.45 & 9.50 \\
P5 & 7.30 & 3.30 & 5.80 \\
\hline
\end{tabular}

Table 2. The concentrations of total flavones, total polyphenols and antioxidant activity for $P$. hibrida from exposure sites

\begin{tabular}{c|ccc}
\hline Samples & TFC quercetin, $\mathrm{mg} / \mathrm{g}$ & TPC Gallic acid, $\mathrm{mg} / \mathrm{g}$ & AO Trolox, $\mathrm{mg} / \mathrm{g}$ \\
\hline P1 & 13.60 & 4.90 & 20,76 \\
P2 & detection below & 5.35 & 15.71 \\
P3 & 12.50 & 5.20 & 10.76 \\
P4 & 12.10 & 6.40 & 12.80 \\
P5 & 9.20 & 2.30 & 3.50 \\
\hline
\end{tabular}

Table 3. The concentrations of total flavones, total polyphenols and antioxidant activity for $R$. comunis from exposure sites

\begin{tabular}{c|ccc}
\hline Samples & TFC quercetin, $\mathrm{mg} / \mathrm{g}$ & TPC Gallic acid, $\mathrm{mg} / \mathrm{g}$ & AO Trolox, $\mathrm{mg} / \mathrm{g}$ \\
\hline P1 & 7.80 & 3.90 & 25,76 \\
P2 & 6.70 & 3.35 & 15.71 \\
P3 & 10.20 & 4.20 & 15.76 \\
P4 & 10.10 & 3.40 & 13.80 \\
P5 & 6.20 & 4.20 & 4.50 \\
\hline
\end{tabular}

Table 4. The concentrations of total flavones, total polyphenols and antioxidant activity for $T$. pratense from exposure sites

\begin{tabular}{c|ccc}
\hline Samples & TFC quercetin, $\mathrm{mg} / \mathrm{g}$ & TPC Gallic acid, $\mathrm{mg} / \mathrm{g}$ & AO Trolox, $\mathrm{mg} / \mathrm{g}$ \\
\hline P1 & 8.20 & 5.70 & 10,76 \\
P2 & 5.80 & 4.35 & 9.73 \\
P3 & 12.00 & 10.20 & 9.76 \\
P4 & 7.20 & 6.20 & 10.80 \\
P5 & 5.20 & 9.30 & 7.50 \\
\hline
\end{tabular}

The analysis of the obtained results highlights the decrease of the inhibition capacity of free radicals in exposed plants to pollutants, from sites and fumigation chamber, compared to unexposed plants (Control). The explanation would be as follows: free radicals can appear as a result of all existing forms of pollution and to balance the situation, the bodies constantly produce certain substances with antioxidant effect. In the case of the existence of pollutants in the environment, the antioxidant capacity of organisms (in our case, exposed plants), is to defend against the decrease of free radicals. In this studied case, there was a sensitization of plant organisms and the appearance of diseases by destroying cells.

In the Figure 6 shows the general appearance of the exposed plants for which the APTI value was calculated. 

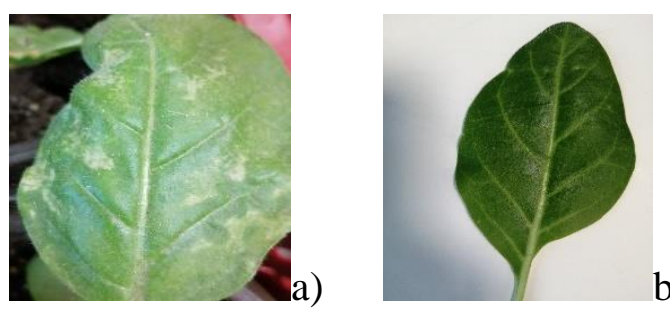

b)

Nicotiana tabacum
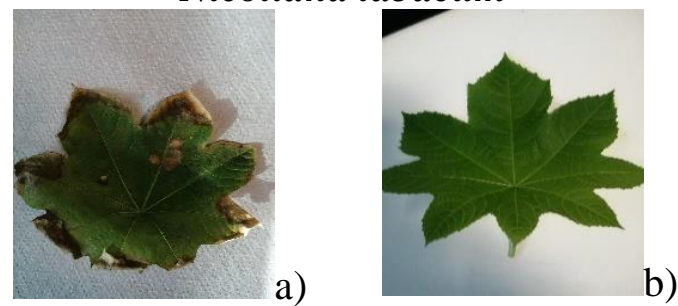

Ricinus comunis
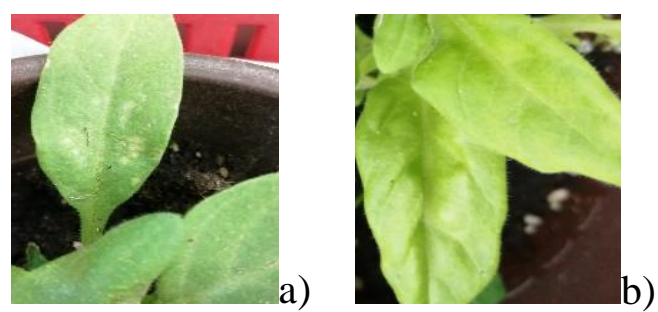

Petunia hibrida
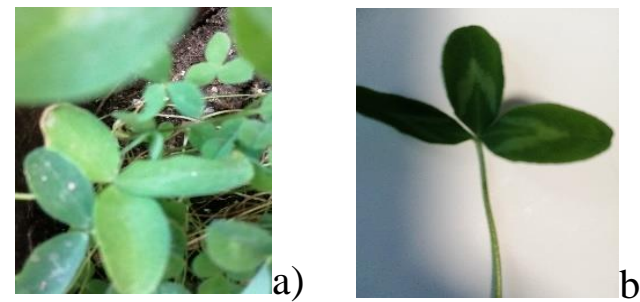

Trifolium pratense

b)

Fig. 6. Representative images of exposed plant species compared to control ones: a) sample from environmental sites; b) control's from climatic chamber

For each type of plant, average / period tests were performed by harvesting and homogenizing leaves from all exposed plants and determining the 4 indicators necessary to calculate the tolerance index. Table 5 presents the sensitivity scale of values and table 6 presents the results of these determinations and the calculated value of APTI for each type of plant and exposure areas.

Table 5. Sensitivity/tolerance assessment scale depending on the APTI value

\begin{tabular}{c|cccc}
\hline Answer & High sensitivity & Sensitive & Intermediary sensitivity & Tolerant \\
\hline APTI value & 1 & $1 \div 16$ & $17 \div 29$ & $30 \div 100$ \\
\hline
\end{tabular}

Table 6. APTI values according to plant species and exposure area

\begin{tabular}{l|ccccc}
\hline \multicolumn{1}{c|}{ Site } & Site 1 & Site 2 & Site 3 & Fumigation chamber & Control's \\
\hline Nicotiana tabacum & 15 & 7 & 14 & 25 & 25 \\
Petunia hibrida & 14 & 12 & 22 & 14 & 14 \\
Ricinus comunis & 17 & 23 & 2 & 28 & 28 \\
Trifolium pratense & 27 & 32 & 24 & 19 & 19 \\
\hline
\end{tabular}

The obtained values show that the species Petunia and Trifolium are the most sensitive for the experiments performed in the fumigation chamber (with known concentrations of pollutants), and in the case of environmental exposure sites (with mixtures of pollutants) the highest sensitivity was at species Nicotiana and Ricinus.

Biomonitoring of air pollution and its impact on biochemical parameters is extremely relevant in the science of air pollution. The study clearly reflects that the tolerance of plants to air pollution may be site-specific. There are also high values at plants exposed in the fumigation chamber, which vary depending on the species.

\section{CONCLUSIONS}

Biomonitoring of air pollution using plants is the method of interest in recent time as it is sustainable and environmentally friendly compared to traditional physical-chemical monitoring. Some plant species are highly sensitive to particular air pollutants and show specific responses to pollutants effects by showing specific damage symptoms. Biomonitoring in the field of air pollution is a broad field of research as there are still many issues to be clarified and it is necessary to develop coherent methods of environmental monitoring through bioindicators, so that they can be used in a concrete way. 
In practice, "sensitive" plant species may be able to provide the information needed to monitor pollution and correlate with the effects of other, more studied biocenosis species.

Biomonitoring methods must be developed to take into account the scale at which the determinations and the data collected are made, so that to be relevant, as well as the way in which these data are processed, stored and interpreted/ evaluated.

\section{ACKNOWLEDGEMENTS}

This study was accomplishing through the "Nucleu" Research Project, developed with the Ministry of Research, Innovation and Digitalization of Romania, Agreement no. 20 N/2019, project code PN - 190402 02. The authors would like to thank all those who contributed to this study.

\section{REFERENCES}

[1] GIORDANO, S., SPAGNUOLO, V., CAPOZZI, F., Atmosphere, 12, no. 4, 2021, p. 433. https://doi.org/10.3390/atmos12040433.

[2] BADAMASI, H., J. Environ. Sci., 2, 2017, p. 27.

[3] GODZIK, B., Atmosphere 11, no. 2, 2020, p.143. https://doi.org/10.3390/atmos11020143.

[4] MAKIOLA, A., COMPSON, Z.G., BAIRD, D.J., BARNES, M.A., BOERLIJST, S.P., BOUCHEZ, A., BRENNAN, G., BUSH, A., CANARD, E., CORDIER, T., CREER, S., CURRY, R.A., DAVID, P., DUMBRELL, A.J., GRAVEL, D., HAJIBABAEI, M., HAYDEN, B., VAN DER HOORN, B., JARNE, P., JONES, J.I., KARIMI, B., KECK, F., KELLY, M., KNOT, I.E., KROL, L., MASSOL, F., MONK ,W.A., MURPHY, J., PAWLOWSKI, J., POISOT, T., PORTER, T.M., RANDALL, K.C., RANSOME, E., RAVIGNÉ, V., RAYBOULD, A., ROBIN, S., SCHRAMA, M., SCHATZ, B., TAMADDONI-NEZHAD, A., TRIMBOS, K.B., VACHER, C., VASSELON, V., WOOD, S., WOODWARD, G., BOHAN, D.A., Front. Environ. Sci., 7, no. 197, 2020, p. 1, https://doi.org/10.3389/fenvs.2019.00197.

[5] JOSHI, N., CHAUHAN, A., JOSHI, P.C., Environmentalist, 29, no. 4, 2009, p. 398, https://doi.org/10.1007/s10669-009-9218-4.

[6] EN 16789:2017: Ambient air. Biomonitoring with the help of higher plants. Standardized method of tobacco exposure.

[7] L. DE TEMMERMAN, BELL, J. B, GARREC, J.P. KLUMPP, A., KRAUSE G.H.M.,. TONNEIJCK A. E.G, Biomonitoring with plants - considerations for the future Biomonitoring of air pollutants with plants - considerations for the future roBionet - Urban Air Pollution, Bioindication and Environmental Awareness

https://www.researchgate.net/publication/40798218_Biomonitoring_of_air_pollutants_with_plants_ -_Considerations_for_the_future [accessed Aug 2 2021].

[8] PASQUALINI, S., BATINI, P., EDERLI, L., PORCEDDU, A., PICCIONI, C., DE MARCHIS F., ANTONIELLI, M., Plant Cell Environ., 24, no.2, 2001, p. 245.

[9] IANOVICI, N., Ann. West Univ. Timiş., Ser. Biol. 19, no. 1, 2016, p. 87.

[10] FINI, A., BRUNETTI, C., DI FERDINANDO, M., FERRINI, F., TATTINI, M., Plant Signal. Behav., 6, no. 5, 2011, p. 709, https://doi.org/10.4161/psb.6.5.15069.

[11] OGUNKUNLE, C.O. SULEIMAN, L.B. OYEDEJI, S. AWOTOYE O.O, FATOBA. P.O., Agroforest Syst., 89, 2015, p. 447.

[12] MARINOVA, D., RIBAROVA, F., ATANASSOVA, M., J., Univ. Chem. Technol. Metallurgy, 40, no.3, 2005, p. 255.

[13] KAMBOJ, A., GUPTA, R., RANA, A., KAUR, R., European J. Biomed. Pharm. Sci., 2, no. 3, 2015, p. 201.

[14] APAK, R., GUCUlU, K., OZYUREK, M., KARADEMIR, P., J. Agric. Food Chem., 52, 2004, p. 7970.

[15] APAK, R., GORINSTEIN, S., BOHM, V., SCHAICH, K.M, OZYUREK, M., GUCLU, K., Pure Appl. Chem., 85, no. 5, 2013, p. 957. http://dx.doi.org/10.1351/PAC-REP-12-07-15.

[16] PARTHA, P., Int. Lett. Nat. Sci., 16, 2014, p. 32, https://doi.org/10.18052/www.scipress.com/ ILNS.16.32. 
[17] APAK, R., DEMIRCI CEKIC, S., UZER, A., ESIN CELIK, S., BENER, M., BEKDESER, B., CAN, Z., SAGLAM, S., NUR ONEM, A., ERCAG, E., Sensors, 18 no. 1, p. 1, https://doi.org/10.3390/s18010186.

[18] ANTONKIEWICZ, J. CZESŁAWA, J., KONCEWICZ-BARAN, M., SENDOR, R., Acta Physiol. Plant, 38, no. 40, 2016, p. 38, https://doi.org/10.1007/s11738-016-2062-5.

[19] GAVRILESCU, M., DEMNEROVA, K. AAMAND, J. AGATHOS, S., FAVA, F., N. Biotechnol., 32, no. 1, 2015 p. 147, https://doi.org/10.1016/j.nbt.2014.01.001.

[20] DIZDARI, A. M., KOPLIKU, D., GOLEMI, S., Mediterr. J. Soc. Sci., 3, no. 8, 2012, p. 241.

Citation: Cozea, A., Tanase, G., Neagu, M., Exposure assessment using biomonitoring, Rom. J. Ecol. Environ. Chem., 2021, 3, no.2, pp. 89-98.

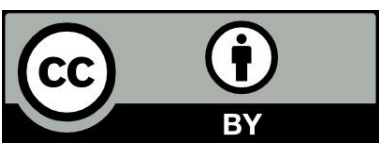

(C) 2021 by the authors. This article is an open access article distributed under the terms and conditions of the Creative Commons Attribution (CC BY) license (http://creativecommons.Org/licenses/by/4.0/). 